\title{
RAD51B Gene Mutation
}

National Cancer Institute

\section{Source}

National Cancer Institute. RAD51B Gene Mutation. NCI Thesaurus. Code C132005.

A change in the nucleotide sequence of the RAD51B gene. 